\title{
Adoption of Technology as a Response Strategy to Globalization: A Study of Manufacturing Firms in Kenya
}

\author{
Solomon Kinyanjui ${ }^{1}$, Margaret A. Oloko ${ }^{2}$, Hazel G. Gachunga ${ }^{1} \&$ Beatrice G. Gathondu ${ }^{3}$ \\ ${ }^{1}$ School of Human Resource Development, Jomo Kenyatta University of Agriculture \& Technology, Nairobi, Kenya \\ ${ }^{2}$ Department of Commerce and Economic Studies, Jomo Kenyatta University of Agriculture and Technology, Nairobi, \\ Kenya \\ ${ }^{3}$ Applied Science, Jomo Kenyatta University of Agriculture and Technology, Karen Campus, Nairobi, Kenya \\ Correspondence: Solomon Kinyanjui, Business Administration, School of Human Resource Development, Jomo \\ Kenyatta University of Agriculture \& Technology, Nairobi, Kenya. E-mail: kinyanjui@solsinclinations.com
}

Received: October 17, 2014

Accepted: November 13, 2014

Online Published: November 17, 2014

doi:10.5430/ijba.v5n6p77

URL: http://dx.doi.org/10.5430/ijba.v5n6p77

\begin{abstract}
Globalization affects local and international firms in many ways. Studies have shown that factors in the internal as well as external environments of firms influence the rate to which globalization will affect them. On the local scene however, no known studies have been done on the response of manufacturing firms to counter globalization. In addition, since the concept of globalization is multidimensional and its influence is varied in nature, this study aimed at investigating how manufacturing firms in Kenya have responded to probable pressure from the forces of globalization in order to sharpen their competitiveness. Cross sectional survey design was adopted for the study. The population for the study was the 735 manufacturing firms in Kenya. The target population of the study were CEOs/MDs and their deputies from 545 manufacturing companies in Nairobi and Athi River. Stratified sampling technique was used to categorize the targeted manufacturing firms into sectors where purposive sampling technique was used to sample the respondents for the study. A total of 100 firms from the 14 sectors were targeted by the study out of which 80 responded giving a response rate of $80 \%$. Questionnaire was used to collect primary data. Regression and correlation analysis was done to test the relationship between the study variables. The study found that $65 \%$ of the respondents agreed that continued global technological advancement has enabled management come up with innovations to respond to customer needs and economic and regulatory factors which have prompted outsourcing some operations, respectively. The results of the correlation analysis show that adoption of technology is statistically significant with a Pearson's Correlation Coefficient of 0.683 and at a level of significance of 0.000 . The study also found out that $67.5 \%$ of the respondents agreed that continued global technological advancement has enabled management come up with innovations to respond to customer needs and economic and regulatory factors which have prompted outsourcing some operations respectively. The null hypotheses that there is no significant relationship between globalization and competition was therefore reject. The study concluded that manufacturing firms in Kenya have adopted technology as response strategies to globalization. The study recommended that manufacturing firms should adopt the new changes in the market and to absorb into the technological trend. Thus, they should remain flexible and stay focused to the day to day changes of globalization strategies.
\end{abstract}

Keywords: adoption of technology, globalization

\section{Introduction}

With the advent of technological changes and e-commerce over the course of the last decade, the role of information technology in business-to-business markets has become crucial. We believe that conceptualizations of business buying behavior in the context of technology have not kept pace with their perceived importance to academics and managers. While academics have increasingly studied supply chains, given the increased possibility of information sharing through IT and the internet, there is a dearth of findings about the new phenomena of the globalization of suppliers (Power, 2005). Global business has primarily been studied from a market expansion perspective, as in the international business literature. Trade barriers, the difficulty of communication, logistics, and travel had hitherto not 
encouraged the global sourcing of business or industrial products. Therefore, there is an urgent need for a better understanding of adoption of technology as a response to globalization.

Globalization has been seen to have significant effects on manufacturing firms across the world - whether positive or negative. This is because manufacturing firms deal with the production of goods. Successful multinational firms do not only venture in any global market but identify the opportunities resulting in a global market, then formulate a strategy that will enable the firm venture successfully. Therefore, a global strategy is a guide giving organizations ways to penetrate in the global markets. Livesey (2006) defines manufacturing as "the transformation of raw materials into finished products." This explains manufacturing firms as those, which handle raw materials and change these raw materials into finished goods. Therefore, given the current opening of global markets, manufacturing firms have been exposed to certain challenges that trigger the management to use diverse methods in response to this competition.

Firms operating in the same country and industry respond to globalization in very different ways. Empirical work using micro-level data on firms or plants initially highlighted this contrast for export decisions and how this decision correlates with observable firm performance measures such as size and productivity: only a subset of relatively bigger and more productive firms export. Bloom, Draca and Van-Reenen (2008) document a relationship between changes in the trading environment, firm innovation and skill upgrading, but on the import competition side. Firms in European industries most exposed to increased import competition from China respond by increasing their innovation and information technology intensity (Bernard, Jensen \& Schott, 2006). Subsequent work has documented a wide ranging set of other responses to globalization that consistently vary across firms in the same country and industry, and are also strongly correlated with firm level performance measures: the number and location of export destinations, entry and exit from the domestic market, the range of products produced, the international organization of production and innovation activities such as research and development.

\subsection{Statement of the Problem}

For a long time Kenya has been known as a nation with adequate political stability compared to its neighbours making it a favourable state to invest in (Muhoro, 2011). The country's weak unions and less saturated market also make Kenya a favourable place for investments (Firestone, Butler, Hardy \& Karlin, 2009). As such, Kenya has attracted many international investors, who have caused competition in the local markets. This forms one of the explanations why the Kenyan market has been filled with products most of them from overseas markets particularly Asian countries like China and India (Miriga, 2010; Nyabiage, 2012). On the flipside however, with the increase in people's and societies' interconnectedness resulting from globalization, there has been continued threats to the stability of Kenya's market environment. These threats have manifested in the form of terrorism and kidnappings of both local and foreign nationals on Kenyan soil.

In Kenya, manufacturers have also had a fair share of challenges. They have struggled to attain a competitive cutting edge against multinational firms operating in the local market (Nyabiage, 2012). Even agricultural-produce manufacturers, though expected to perform well locally due to adequate availability of raw materials, have faced rapid competition from imported products. These challenges have affected local manufacturers trading internationally and locally. The statistics on the contribution of Kenya Gross Product by activity measured in market prices show that the contribution of the manufacturing sector is on the uptrend (KAM, 2011). On the side of growth rates by industry, statistics show that the growth of the manufacturing sector has been fluctuating with 2009 registering the lowest growth of 1.3\% from the previous 3.5\%, which later recovered in 2010 and 2011 (KAM, 2011).

There is a possibility that these fluctuations are caused by intensifying globalization and its effects on manufacturing firms. While a number of literary articles present discussions on globalization and its influence on business, little has been done to try to understand how firms are coping or responding to the ever-changing nature of globalization. According to Honkala, Goldstein, Thul, Baptist and Grugan (1999), inadequate response to the globalization phenomenon has made some countries like USA to observe increases in poverty levels. They further assert that this increase in levels of poverty has seen the gap between the rich and poor widening as poor people are denied better payment and jobs while higher profits and reduced costs continues to be experienced by corporation owners. Of particular importance is that such information in regard to manufacturing firms in Kenya is truly lacking. The reality is that globalization is an unavoidable phenomenon, and as such, this study sought to establish the adoption of technology as a response strategy to globalization by manufacturing firms in Kenya. 


\section{Literature Review}

This section presents theoretical and empirical review.

\subsection{Transformational Theory}

Transformationalist perspective holds that there is no single cause (be it the market or economic logic) behind globalization; and that the outcome of processes of globalization is not determined (Held, McGrew, Goldblatt \& Perraton, 1999). According to Held et al. (1999), transformationalist scholars' approach to globalization process is significantly less certain on the historical lines of changes of globalization. The perspective is also less limiting of the drivers of globalization. According to transformationalists, viewing the globalization process in terms of it reducing the power of nations (as hyperglobalists do) or enhancing the power of nations (as skeptics do) is being extreme and oversimplifying the whole concept. They argue that the globalization process should be looked at in terms of changing the nature of national governments through reconstitution and restructuring rather than growing or waning (Held \& McGrew, 2007).

While hyperglobalists describe the attrition of old, models of stratification; and skeptics argue that globalization is marginalizing the southern nations, transformationalists posit a somewhat harmonizing view that globalization process is creating a new world order except that the true nature of the resultant patterns of stratification is yet to be defined. The conclusion of transformationalists is that a larger number of factors influence the process of globalization and the outcomes of this process are highly less certain (Held \& McGrew, 2007).

Some two key concerns about the hyperglobalist and skeptical perspectives on globalization are that; first, they significantly focus on teleology in globalization, which is highly less accurate. The two perspectives link the current processes of globalization to ideal cases, which is hard to achieve. They also argue that the processes of globalization are automatically making linear progress towards the ideal outcomes.

Second is that the two perspectives are unacceptably empiricist. Statistical patterns should be interpreted based on a range of meanings (Held et al., 1999). These limitations deny the process of globalization to be understood in sophisticated terms apart from observation hence the questionability of the skeptical and the hyperglobalist perspectives.

This study, just like other scholars have done, embraces the transformationalists theory as the main theory with ideas useful in discussing its findings since it presents globalization as without strict judgment as has been seen in the other theories. However, ideas from the other theories were borrowed in the study's discussions nevertheless.

\subsection{Adoption of Technology and Globalization}

Archibugi and Pietrobelli (2002) did a study to explore the impact of the different forms of the globalization of technology on developing countries. They found that through travelling, media, scientific and technical workshops, Internet and many other communication channels, globalization allows the transmission of knowledge at a much greater pace than in the past. However, this does not automatically imply that developing countries succeed to benefit from technological advances. On the contrary, this will strongly rely on the nature of the technology and of the policies implemented in both advanced and developing countries.

Dahlman (2006) did a study on the challenges that developing countries face in technology, globalization and international competitiveness. He traced the role of technology in economic growth and competitiveness, summarized the strategies of the fastest growing economies over the last 50 years from the perspective of their technology strategy, summarized some of the key global trends which are making it more difficult for developing countries to replicate the fast growth experience of the countries mentioned, and traces the impact of the rise of China on developing countries. The main argument of the paper is that technology is an increasingly important element of globalization and of competitiveness and that the acceleration in the rate of technological change and the prerequisites necessary to participate effectively in globalization are making it more difficult for many developing countries to compete.

Lee (2006) did a study on the social impact of globalization in the developing countries. He used an ex-post measurable definition of globalization, namely increasing trade openness and FDI. He found that: 1) the employment effect can be very diverse in different areas of the world, giving raise to concentration and marginalization phenomena; 2) increasing trade and FDI do not emerge as the main culprits of increasing within-country income inequality in developing countries, although some evidence emerges that import of capital goods may imply an increase in inequality via skill-biased technological change; and 3) increasing trade seems to foster economic growth. 
With the opening of borders to trade and foreign investment, globalization brings opportunities and pressures for domestic firms in emerging market economies to innovate and improve their competitive position. Many of these pressures and opportunities operate through increased competition from and linkages with foreign firms.

Useful knowledge has not necessarily become more evenly spread out across space, as Chesbrough (2003) claim; rather linkages are created between specialized knowledge development nodes located in places which are increasingly more geographically dispersed. Knowledge flows across actors and space as embodied in machinery or components; and between industries or firms with very different degrees of Research and Development (R \& D) intensity and knowledge base characteristics. Low-tech firm users are linked to high-tech knowledge providers, and vice versa; innovation in individual firms by necessity becomes linked to interfacing with lead users located elsewhere; and to interfacing with leading suppliers, research institutes or universities that are more and more likely to be located outside of the immediate surrounding environment.

The intensity of innovation-based competition is increasing, in part triggered by the rise of India and China as major international players. Symptomatic of all this is the internationalization of corporate enterprises and innovation. Whereas we still see that market access or proximity to key users remains the single most important driver of such internationalization in general, the proportion of corporate $\mathrm{R} \& \mathrm{D}$ performed outside domestic countries is increasing rapidly (Granstrand, 1999). The most important overall motive for this shifting of $\mathrm{R} \& \mathrm{D}$ activities remains customization of technologies to suit local market conditions, but there is clear evidence that technology sourcing plays an increasingly important role (UNCTAD, 2005). This all means that national innovation systems or clusters are forced to open up. This study will therefore find out whether manufacturing firms in Kenya have adopted the use of technology in their response to globalization.

\section{Methodology}

This study was carried out in manufacturing companies registered with KAM in Nairobi County and Athi River in Mavoko Sub-County of Machakos County. The study targeted the senior most ranking officer (MDs or CEOs) and their deputies. The study targeted those manufacturing companies who are registered with KAM and are based in the selected regions. The target population for the study was therefore $560(80 \%$ of 700$)$ manufacturing companies. The study targeted 100 companies in the following sectors: building, mining and construction; chemical and allied; energy, electrical and electronics; fresh produce; food and beverage; leather and foot ware; metal and allied; paper and board; pharmaceutical and medical equipment; plastics and rubber; services and consultancy; textiles and apparels; and timber, wood and furniture. A total of 80 companies participated in the study. Questionnaires were used as instrument for data collection. Both quantitative and qualitative data analysis techniques were used. Quantitative data was analyzed using descriptive statistics while qualitative data was analyzed thematically. Inferential statistics such as correlation and regression analysis were used to test on the relationship between the variables of the study.

Linear regression model was used in the study

$$
\mathrm{Y}=\beta_{0}+\beta_{1} \mathrm{X}_{1}+\varepsilon
$$

Where:

$\mathrm{Y}$ is the dependent variable (Globalization)

$\mathrm{X}$ is the independent variable, i.e.

$\mathrm{X}_{1}$ - Adoption of Technology

$\beta_{i(i=l)}$ was the parameters associated with the corresponding independent variable that was estimated (partial regression coefficients)

$\beta_{0}$ is the intercept

$\varepsilon$ is the error variability (error term)

\section{Findings of the Study}

The study adopted factor analysis in order to reduce the number of indicators or factors under each research variable and retain the indicators capable of explaining the responses to globalization adopted by manufacturing firms in Kenya. The retained factors had loading values of above 0.4 and were used for further analysis. Hair et al. (1998) recommends use of factors with factor loading above 0.4. This is also supported by Tabachnick and Fidell (2007) using more stringent cut offs going from 0.32 (poor), 0.45 (fair), 0.55 (good), 0.63 (very good) or 0.71 (excellent). 
To measure the reliability of the gathered data, Cronbach's alpha was used. Cronbach's alpha is a coefficient of reliability that gives an unbiased estimate of data generalizability (Zinberg, 2005). An alpha coefficient of 0.70 or higher indicated that the gathered data is reliable as it has a relatively high internal consistency and can be generalized to reflect opinions of all respondents in the target population (Zinbarg, 2005). The following sub-sections present factor analysis for the indicators of adoption of technology.

Table 1 shows Cronbach's alpha of all indicators. Cronbach's alpha results in the component column were computed using the results of all indicators. The results revealed that all the indicators/factors had a loading of more than 0.4.

Table 1. Adoption of technology reliability and factor analysis results

\begin{tabular}{lcc}
\hline & Component & Cronbach alpha \\
\hline $\begin{array}{l}\text { Global economic factors such as trade blocks has widened supply chain } \\
\text { network making us adopt logistic technologies }\end{array}$ & .807 & .840 \\
$\begin{array}{l}\text { Global social standards has influenced adoption product design technologies } \\
\begin{array}{l}\text { Development in global communication has contributed to our firm acquiring } \\
\text { advanced information exchange technologies }\end{array}\end{array}$.783 & .780 \\
$\begin{array}{l}\text { Regulatory measures has influenced adoption of environmental friendly } \\
\text { technologies }\end{array}$ & .780 \\
$\begin{array}{l}\text { Global social forces influenced by social technological networks has made us } \\
\text { embrace communication technologies }\end{array}$ & .739 \\
$\begin{array}{l}\text { Global economic forces has made our firm to constantly adopt new product } \\
\text { design technologies }\end{array}$ & .648 \\
$\begin{array}{l}\text { Diffusion of technology globally has facilitated our firm adopting information } \\
\text { dissemination and communication technologies }\end{array}$ & .526 \\
$\begin{array}{l}\text { Continued global technological advancement has influenced our firm to } \\
\text { embrace superior process technologies }\end{array}$ & .404
\end{tabular}

Table 1 shows that Cronbach's alpha result of all adoption of technology indicators was 0.840 and the factor loading results were between 0.404 and 0.807 . This implies that all the indicators were retained for further analysis. Using all adoption of technology indicators, the value of Cronbach's alpha was computed again and generated similar value of 0.840 . This indicated that data collected using all the adoption of technology indicator values was reliable since the Cronbach's alpha value was above 0.70 . The study hence deduced that all the eight adoption of technology indicators were reliable in determining the use of technology as a response to globalization. These indicators were later used for further analysis.

Descriptive statistics were used to describe the basic features of the data in the study. They provide simple summaries of the sample and measures. Descriptive statistics such as frequencies and percentages were used to analyze the data.

Table 2. Adoption of technology versus globalization as a threat

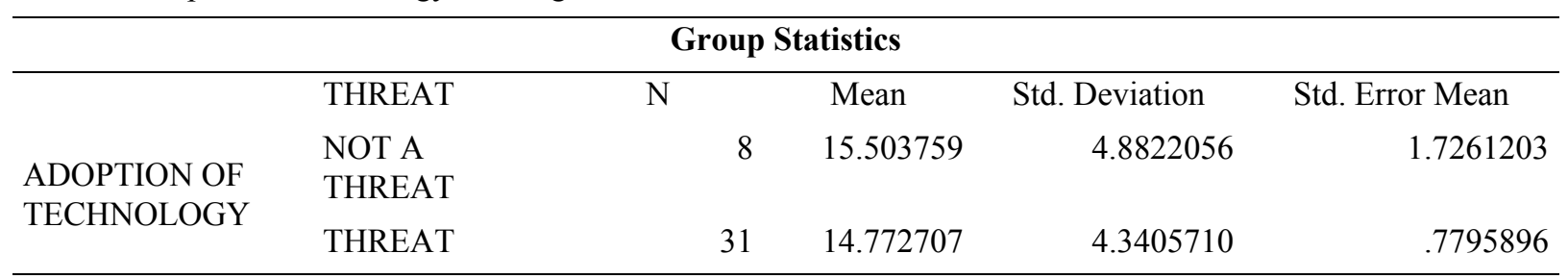

The difference between the two means is insignificant an indication that there is no significant difference in adoption of technology and perception of globalization as a threat. 
Table 3. T-test for equality of means for adoption of technology

\begin{tabular}{|c|c|c|c|c|c|c|c|c|}
\hline & & \multicolumn{7}{|c|}{ t-test for Equality of Means } \\
\hline & & \multirow[t]{2}{*}{$\mathrm{t}$} & \multirow[t]{2}{*}{ df } & \multirow{2}{*}{$\begin{array}{c}\text { Sig. } \\
\text { (2-tailed } \\
\text { ) }\end{array}$} & \multirow[t]{2}{*}{$\begin{array}{c}\text { Mean } \\
\text { Difference }\end{array}$} & \multirow[t]{2}{*}{$\begin{array}{l}\text { Std. Error } \\
\text { Difference }\end{array}$} & \multicolumn{2}{|c|}{$\begin{array}{l}95 \% \text { Confidence Interval } \\
\text { of the Difference }\end{array}$} \\
\hline & & & & & & & Lower & Upper \\
\hline $\begin{array}{l}\text { ADOPTIO } \\
\text { N OF }\end{array}$ & $\begin{array}{l}\text { Equal } \\
\text { variances } \\
\text { assumed }\end{array}$ & .414 & 37 & .681 & .7310521 & 1.7639301 & -2.8430098 & 4.3051141 \\
\hline $\begin{array}{l}\text { TECHNOL } \\
\text { OGY }\end{array}$ & $\begin{array}{l}\text { Equal } \\
\text { variances not } \\
\text { assumed }\end{array}$ & .386 & 10.049 & .708 & .7310521 & 1.8940040 & -3.4862401 & 4.9483443 \\
\hline
\end{tabular}

Table 3 shows that there is no significant difference in adoption of technology between companies which saw globalization as a threat and those which did not at $95 \%$ level of confidence.

\subsection{Adoption of Technology and Globalization}

To test on the adoption of technology, the respondents were asked to indicate their level of agreement with different statements on the adoption of technology. The findings of the study were as presented in Table 4.

Table 4. Adoption of technology

\begin{tabular}{|c|c|c|c|c|c|c|}
\hline & $\begin{array}{l}\text { Strongly } \\
\text { Disagree }\end{array}$ & Disagree & $\begin{array}{c}\text { Not } \\
\text { Applicable }\end{array}$ & Agree & $\begin{array}{l}\text { Strongly } \\
\text { Agree }\end{array}$ & Total \\
\hline $\begin{array}{l}\text { Continued global technological advancement } \\
\text { has influenced our firm to embrace superior } \\
\text { process technologies }\end{array}$ & $0.0 \%$ & $0.0 \%$ & $0.0 \%$ & $35.0 \%$ & $65.0 \%$ & $100.0 \%$ \\
\hline $\begin{array}{l}\text { Global economic forces has made our firm to } \\
\text { constantly adopt new product design } \\
\text { technologies }\end{array}$ & $0.0 \%$ & $0.0 \%$ & $5.0 \%$ & $55.0 \%$ & $40.0 \%$ & $100.0 \%$ \\
\hline $\begin{array}{l}\text { Development in global communication has } \\
\text { contributed to our firm acquiring advanced } \\
\text { information exchange technologies }\end{array}$ & $0.0 \%$ & $0.0 \%$ & $5.0 \%$ & $45.0 \%$ & $50.0 \%$ & $100.0 \%$ \\
\hline $\begin{array}{l}\text { Diffusion of technology globally has } \\
\text { facilitated our firm adopting information } \\
\text { dissemination } \\
\text { technologies }\end{array}$ & $1.3 \%$ & $1.3 \%$ & $2.5 \%$ & $53.8 \%$ & $41.3 \%$ & $100.0 \%$ \\
\hline $\begin{array}{l}\text { Global social forces influenced by social } \\
\text { technological networks has made us embrace } \\
\text { communication technologies }\end{array}$ & $0.0 \%$ & $1.3 \%$ & $5.0 \%$ & $62.5 \%$ & $31.3 \%$ & $100.0 \%$ \\
\hline $\begin{array}{l}\text { Regulatory measures has influenced adoption } \\
\text { of environmental friendly technologies }\end{array}$ & $0.0 \%$ & $11.3 \%$ & $7.5 \%$ & $47.5 \%$ & $33.8 \%$ & $100.0 \%$ \\
\hline $\begin{array}{l}\text { Global economic factors such as trade blocks } \\
\text { has widened supply chain network making us } \\
\text { adopt logistic technologies }\end{array}$ & $0.0 \%$ & $1.3 \%$ & $28.8 \%$ & $43.8 \%$ & $26.3 \%$ & $100.0 \%$ \\
\hline $\begin{array}{l}\text { Global social standards has influenced } \\
\text { adoption product design technologies }\end{array}$ & $0.0 \%$ & $7.5 \%$ & $12.5 \%$ & $35.0 \%$ & $45.0 \%$ & $100.0 \%$ \\
\hline
\end{tabular}

The findings on Table 4 shows that $65 \%$ of the respondents strongly agreed that continued global technological advancement has influenced their firms to embrace superior process technologies. The finding suggests that firms are responding to the effects of globalization through innovation and adoption of technology. 
The study also found out that $62.5 \%$ of the respondents agreed that global social forces influenced social technological networks has made us embrace communication technologies and that $55 \%$ of the respondents agreed that global economic forces has made their firms to constantly adopt new product design technologies. This is an indication that adoption of technology is one of the strategies which has been adopted as a response to globalization by manufacturing firms in Kenya.

\subsection{Correlation Analysis}

This study conducted correlation analysis to test on the strength of association/relationship between the study variables. Correlation is a measure of the relationship or association between two continuous numeric variables. It indicates both the direction and degree to which they vary with one another from case to case without implying that one is causing the other. Correlation analysis results give a correlation coefficient which measures the linear association between two variables (Crossman, 2013).

Values of the correlation coefficient range between -1 and +1 . A correlation coefficient of +1 indicates that two variables are perfectly related in a positive linear. A correlation of -1 indicates that two variables are negatively linearly related and a correlation efficient of 0 indicates that there is no linear relationship between two variables (Wond, 2012).

To clearly show the correlation analysis results, the study used scatter plots diagrams. A scatter plot diagram is a graph that shows the relationship between two quantitative variables. Scatter plots are used to investigate the possible relationship between two variables.

When interpreting the scatter diagram, the issues to $\mathrm{b}$ considered includes:

If the points scatter in a band running from lower left to upper, there is a positive correlation (if $\mathrm{X}$ increase, $\mathrm{Y}$ increases).

If the points cluster in a band from upper left to lower right, there is a negative correlation (if $\mathrm{X}$ decreases, $\mathrm{Y}$ increases)

When a straight line is drawn or curve through the data so that it fits as well as possible, the more points cluster closely around the line of best fit, the stronger the relationship that exists between two variables (Rumsey, 2012).

To establish whether adoption of technology was one of the responses to globalization, a scatter plot diagram of the correlation of adoption of technology and globalization was plotted

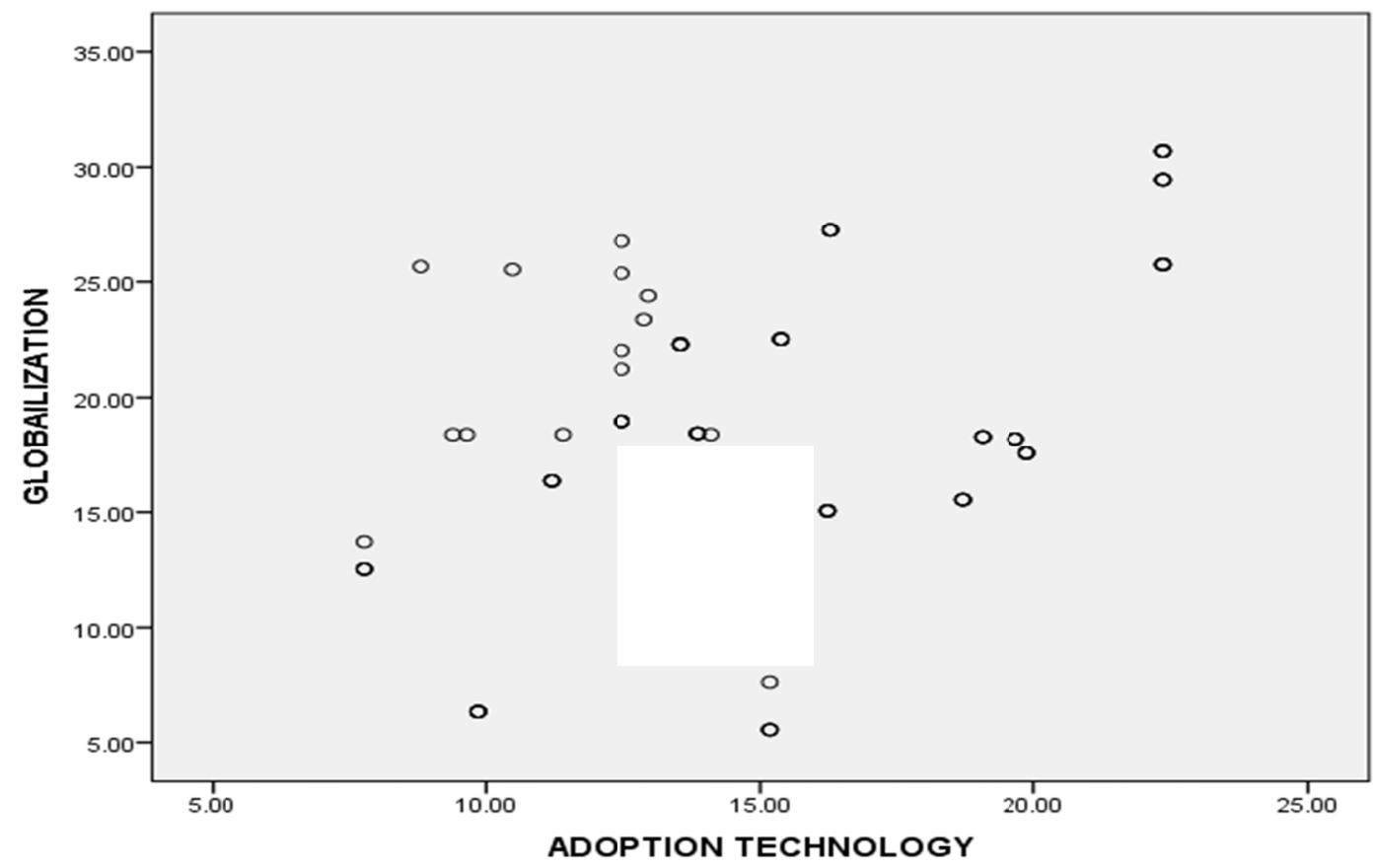

Figure 1. Adoption of technology correlations analysis 
Figure 1 shows a scatter plot diagram of correlation of adoption of technology versus globalization. As can be observed in the figure, all points tend to concentrate in the centre of the diagram. These findings imply that there is a strong positive correlation between adoption of technology and globalization

The symmetric matrix with Pearson correlations given below in Table 4.34 shows that the Pearson correlation coefficient was 0.475 and this demonstrates that adoption of technology have a positive correlation with globalization.

Table 5. Correlations

\begin{tabular}{|c|c|c|c|}
\hline \multicolumn{4}{|c|}{ Correlations } \\
\hline & & GLOBAILIZA & ADOPTION TECHNOLOGY \\
\hline \multirow{3}{*}{ GLOBAILIZATION } & Pearson Correlation & 1 & $.475^{* *}$ \\
\hline & Sig. (2-tailed) & & .000 \\
\hline & $\mathrm{N}$ & 80 & 80 \\
\hline \multirow{3}{*}{$\begin{array}{l}\text { ADOPTION } \\
\text { TECHNOLOGY }\end{array}$} & Pearson Correlation & $.475^{* *}$ & 1 \\
\hline & Sig. (2-tailed) & & \\
\hline & $\mathrm{N}$ & & 80 \\
\hline
\end{tabular}

\subsection{Regression Analysis}

Regression analysis was further carried out to establish the statistical significance between the study variables. Regression analysis was presented using regression model summary tables, Analysis Of Variance (ANOVA) table and beta coefficient tables.

\section{Regression Analysis on Adoption of Technology and Globalization}

Regression analysis was done to determine the relationship between adoption of technology and globalization.

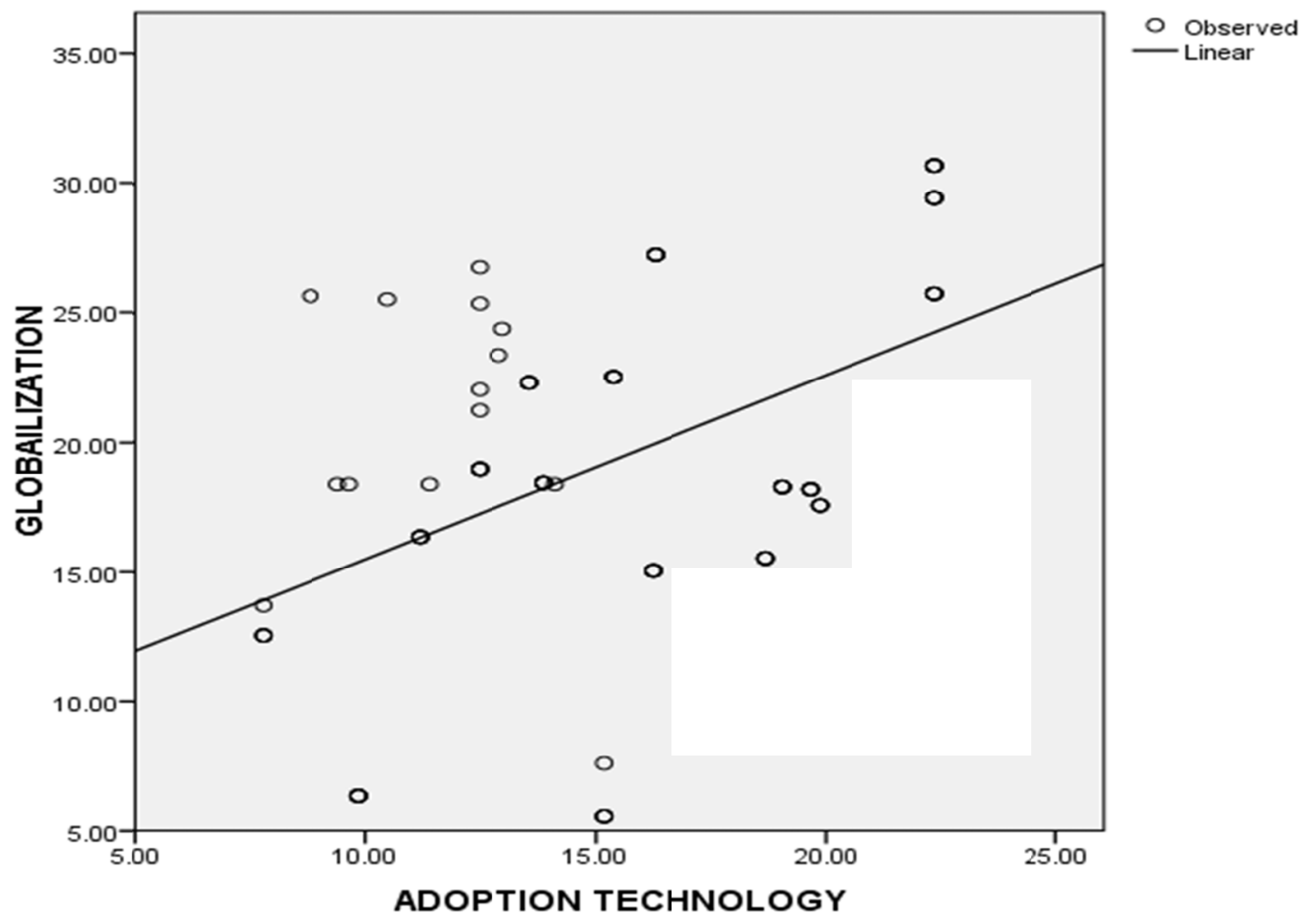

Figure 2. Regression analysis on adoption of technology and globalization 
Table 6 shows that the coefficient of determination $\mathrm{R}$ square is 0.226 and $\mathrm{R}$ is 0.475 at 0.05 significant level. The coefficient of determination indicates that $22.6 \%$ of the variation in the response to globalization is explained by adoption to technology.

Table 6. Regression

\section{Model Summary}

\begin{tabular}{lllll}
\hline Model & $\mathrm{R}$ & R Square & Adjusted R Square & Std. Error of the Estimate \\
1 & $.475 \mathrm{a}$ & .226 & .216 & 5.79974 \\
\hline
\end{tabular}

a. Predictors: (Constant), ADOPTION TECHNOLOGY

Table 7 presents the results of Analysis of Variance (ANOVA) on adoption of technology versus globalization. The ANOVA results for regression coefficient indicates that the significance of the $F$ is 0.00 which is less than 0.05 hence implying that there is a positive significant relationship between adoption of technology and globalization. These findings are in line with Dahlman (2006) findings that technology is an increasingly important element of globalization and that the acceleration in the rate of technological change is making it more difficult for many developing countries to compete.

Table 7. ANOVA

\begin{tabular}{llccccc}
\hline \multicolumn{7}{c}{ ANOVA $^{\mathbf{a}}$} \\
\hline Model & & Sum of Squares & df & Mean Square & F & Sig. \\
& Regression & 764.000 & 1 & 764.000 & 22.713 & $.000^{\mathrm{b}}$ \\
\cline { 2 - 6 } & Residual & 2623.681 & 78 & 33.637 & & \\
& Total & 3387.680 & 79 & & & \\
\hline
\end{tabular}

a. Dependent Variable: GLOBAILIZATION

b. Predictors: (Constant), ADOPTION TECHNOLOGY

Further analysis determined beta coefficients of adoption of technology versus globalization. Table 8 shows that there is significant relationship between adoption of technology and globalization. Since the coefficient of adoption of technology is 0.709 which is statistically greater than zero. The $t$ statistic is 4.766 which is greater than zero. This demonstrates that adoption of technology have a positive influence on globalization.

Table 8. Coefficients

\begin{tabular}{|c|c|c|c|c|c|c|}
\hline \multicolumn{7}{|c|}{ Coefficients } \\
\hline \multirow{2}{*}{\multicolumn{2}{|c|}{ Model }} & Unstand & oefficients & Standardized Coefficients & $\mathrm{t}$ & Sig. \\
\hline & & B & Std. Error & Beta & & \\
\hline & (Constant) & 8.402 & 2.404 & & 3.496 & .001 \\
\hline 1 & $\begin{array}{l}\text { ADOPTION } \\
\text { TECHNOLOGY }\end{array}$ & .709 & .149 & .475 & 4.766 & .000 \\
\hline
\end{tabular}

a. Dependent Variable: GLOBAILIZATION

The alternative hypothesis that there is significant relationship between adoption of technology and globalization is the therefore accepted (P. value is 0.000 ). Thus, adoption of technology is used as a response to globalization.

\section{Discussion}

The factor analysis result on adoption of technology had a Cronbach's alpha of 0.840 . The study therefore deduced that all the adoption of technology indicators to be reliable in assessing adoption of technology as a response to globalization in the manufacturing firms in Kenya. All the adoption of technology factors such as technological advancement, diffusion of technology, global economic forces, global social forces and global communication were later used for further analysis.

Descriptive statistics results showed that adoption of technology is one of the responses by manufacturing firms to globalization. This is evidenced by $65 \%$ of the respondents strongly agreeing that continued global technological advancement has influenced their firms to embrace superior process technologies. According to Buckley and Ghauri 
(2004) did a study to examine globalization in terms of conflicts between markets and economic management and found that the major challenge to manufacturing firms is brought about by fast and unstoppable advances in information technologies, market deregulation and large reductions in transport costs, which together constitute what is commonly called globalization. These aspects put together define a new and more intensely competitive scenario and, in this way, globalization has become one of the phenomena that better explains the recent competition among manufacturing firms.

The study further found $62.5 \%$ of the respondents agreed that global social forces influenced social technological networks has made us embrace communication technologies. According to Castells (1999), the ability to move into the information age depends on the capacity of the whole society to be educated, and to be able to assimilate and process complex information. This starts with the education system. This as well relates to the overall process of cultural development, including the level of functional literacy, the content of the media, and the diffusion of information within the population as a whole. Archibugi and Pietrobelli (2002) in their study to explore the impact of the different forms of the globalization of technology on developing countries found that through traveling, media, scientific and technical workshops, Internet and many other communication channels, globalization allows the transmission of knowledge at a much greater pace than in the past. Thus the social technological networks are used as a strategy to get information on technological products and even in the exploration of the new markets.

The study also found that $55 \%$ of the respondents agreed that global economic forces have made their firms to constantly adopt new product design technologies. This finding is supported by the findings of a study by Dahlman (2006) who found technology is an increasingly important element of globalization and of competitiveness and that the acceleration in the rate of technological change and the pre-requisites necessary to participate effectively in globalization are making it more difficult for many developing countries to compete. From the findings of the study, it can be said that adoption of technology is one of the strategies, which has been adopted as a response to globalization by manufacturing firms in Kenya.

Pearson correlation analysis of adoption of technology results gave a correlation of 0.475 which demonstrated that adoption of technology has a positive correlation with globalization. Regression model of adoption of technology versus globalization gave a coefficient of determination of $R$ square of 0.226 and $R$ is 0.475 at 0.05 significant level. The coefficient of determination indicated that $22.6 \%$ of the response to globalization is explained by adoption of technology. This implies that there exists a strong positive relationship between adoption of technology and response to globalization.

\section{Summary of Findings}

Adoption of technology was found to be one of the response strategies to globalization used by manufacturing firms in Kenya. The findings of the study revealed that $65 \%$ of the respondents strongly agreed that continued global technological advancement has influenced their firms to embrace superior process technologies. The study also found out that $62.5 \%$ of the respondents agreed that global social forces influenced social technological networks has made us embrace communication technologies and 55\% agreed that global economic forces has made our firm to constantly adopt new product design technologies. These findings are indications that as a result of globalization, different technological response strategies have been developed.

These findings are corroborated with the findings by Dahlman (2006) who found that technology is an increasingly important element of globalization and of competitiveness and that the acceleration in the rate of technological change and the pre-requisites necessary to participate effectively in globalization are making it more difficult for many developing countries to compete. As a result, manufacturing firms are adopting technology to respond to the threats by globalization.

The findings from correlation analysis revealed that globalization is positively related with the adoption of technology with a Pearson's Correlation Coefficient of $r=0.683$ and at a level of significance of 0.000 , an indication that technology is statistically significant with $\mathrm{p}$ value less than 0.05 . The alternative hypothesis that there is significant relationship between adoption of technology and globalization is therefore accepted. The alternative hypothesis that there is significant relationship between adoption of technology and globalization is the therefore accepted (P. value is 0.000 ). Thus, adoption of technology is used as a response to globalization. The findings are in line with the findings by Mussa (2000) who found that globalization has led to the opening up of national boundaries due to tastes, technology, and public policy, which interact in important ways. Mussa presented political, economic, and social factors as key drivers of globalization such that social factors such as tastes of people attract economic benefits to those who respond to such tastes through using appropriate technology to either produce or supply to such tastes. 


\section{Conclusions}

Based on the findings of the study, a conclusion was drawn that that manufacturing firms in Kenya have adopted the use of technology, managerial innovation, resource management, distribution chain and competition as response strategies to globalization.

Adoption of technology was found to be one of the key response strategies to globalization. Due to the continued global technological advancement, manufacturing firms in Kenya have embraced superior process technologies aimed at reducing the cost of production while maximizing profits. Technological factors adopted as response strategies to globalization include: technological advancement, diffusion of technology and global communication strategies. The study thus concludes that adoption of technology is one of the key response strategies to globalization adopted by manufacturing firms in Kenya. These conclusions were also drawn by other scholars, who found that the major challenge to manufacturing firms is brought about by fast and unstoppable advances in information technologies. The finding thus justifies the adoption of technology as a key response strategy to globalization.

\section{Recommendations}

Manufacturing firms should adopt the new changes in the market and to absorb into the technological trend. Thus, they should remain flexible and stay focused to the day to day changes of globalization strategies. This is based on the fact that even though most manufacturing firms in Kenya have adopted the use of technology as a response strategy to globalization, a lot still needs to be done

\section{References}

Archibugi, D., \& Pietrobelli, C. (2002). The globalisation of technology and its implications for developing countries Windows of opportunity or further burden? Technological Forecasting \& Social Change, 70(2003), 861-883.

Bernard, A. B., Jensen, J. B., \& Schott, P. K. (2006). Survival of the best .t: Exposure to low-wage countries and the (uneven) growth of US manufacturing plants. Journal of International Economics, 68(1), 219-237.

Bloom, N., Draca, M., \& Van-Reenen, J. (2008). Trade induced technical change? The impact of Chinese imports on IT and innovation. Mimeo. Mimeo.

Buckley, P.J., \& P.N. Ghauri. (2004). Globalization,economic geography and the strategy of multinational enterprises. Journal of International Business Studies, 35, 81-98

Chesbrough, H. (2003). Open Innovation. Cambridge, Mass: Harvard University Press.

Crossman, A. (2013). Convergence theory. About.com sociology. Retrieved December 04, 2013, from http://sociology.about.com/od/C_Index/g/Convergence-Theory.htm

Dahlman, C. (2006). Technology, Globalization, and Competitiveness: Challenges for Developing Countries; Industrialization in the 21rst Century. New York.

Firestone, M., Butler, S., Hardy, P., \& Karlin, A. (2009). Lonely Planet (e-Book Edi.). Nairobi, Kenya.

Granstrand, O. (1999). Internationalisation of Corporate R\&D. Research Policy, 8(2-3).

Held, D., \& McGrew, A. (2007). Globalization Theory: Approaches and Controversies. Cambridge, Mass: Polity.

Held, D., McGrew, A., Goldblatt, D., \& Perraton, J. (1999). Global Transformations: Politics, Economics and Culture. Stanford, CA: Stanford University Press.

Honkala, C., Goldstein, R., Thul, E., Baptist, W., \& Grugan, P. (1999). Globalization and homelessness in the USA: Building a social movement to end poverty. Development in Practice, 9(5), 526-538.

Lee, E. (2006). The social impact of globalization in the developing countries (No. 1925).

Livesey, F. (2006). Defining High Value Manufacturing. University of Cambridge.

Miriga, J. (2010). Chinese Invasion Factor in Kenya and Africa. Retrieved August 20, 2012, from http://socioeconomicforum50.blogspot.com

Muhoro, M. W. (2011). An Assessment of the Impact of Globalization on Strategic Planning Practices at Standard Chartered Bank of Kenya. University of Nairobi.

Mussa, M. (2000). Factors Driving Global Economic Integration. In Jackson Hole, Wyoming symposium on Global Opportunities and Challenges.

Nyabiage, J. (2012, September 25). Raid of the continent by Chinese. Standard Digital.

Power, D. (2005). Determinants of business-to-business e-commerce implementation and performance: a structural model. Supply Chain Management, 10(2), 96.

Tabachnick, B.G., \& Fidell, L.S. (2001). Using Multivariate Statistics. Boston: Allyn and Bacon.

UNCTAD. (2004). World Investment Report: The Shift towards Services. Geneva. 